\title{
EFFECT OF BALANCED DIET EDUCATION WITH MEDIA COMIC ON MODIFICATION OF EATING BEHAVIOR IN ADOLESCENTS AT MIDDLE SCHOOL, MALANG
}

\author{
Rani Nurmayanti, I Nengah Tanu Komalyna, Sugeng Iwan Setyobudi Maryam \\ Razak
}

Nutrition Department Malang State Health Polytechnic

\begin{abstract}
Background: Obesity remains the main malnutritional problem globally. One of the contributing factors is the imbalance diet eating behavior. This study aimed to analyze the effect of balanced diet education with media comic on modification of eating behavior in adolescents at middle school, Malang, East Java.

Subjects and Method: A randomized control trial study was conducted at Middle School, Malang, East Java, in November 2018. A sample of 64 students was randomized into two groups: (1) Experiment group that received diet education using media comic, and (2) Control group that received no intervention. The dependent variables were knowledge, attitude, and skill of eating behavior. The independent variable was diet education using media comic. The data were analyzed by independent t-test.

Results: After the intervention, the experimental group had higher mean of knowledge $($ Mean=92.72; $\mathrm{SD}=10.78)$, attitude $(\mathrm{Mean}=83.23 ; \mathrm{SD}=18.13)$, and skill $(\mathrm{Mean}=78.79$; $\mathrm{SD}=16.94$ ) than the control group, including knowledge (Mean= 88.68; $\mathrm{SD}=11.47$ ), attitude (Mean= 87.60; $\mathrm{SD}=8.60$ ), and skill (Mean= 79.94; $\mathrm{SD}=14.31$ ), and it was statistically insignificant in each outcomes, $(\mathrm{p}=0.151),(\mathrm{p}=0.223)$, and $(\mathrm{p}=0.770)$ respectively.

Conclusion: Diet education with media comic is effective in improving knowledge, attitude, and skill of eating behavior in students, but it is not statistically significant.

Keywords: diet education, media comic, eating behavior, balanced diet

Correspondence:

Rani Nurmayanti. School of Health Polytechnics, Ministry of Health. Jl Besar Ijen 77C Malang, East Java. Email: freshrunz@gmail.com. Mobile: +6285258334321.
\end{abstract}

